\title{
POPULATION STRUCTURE, SIZE AT FIRST SEXUAL MATURITY, AND FEEDING ECOLOGY OF CONODON NOBILIS (ACTINOPTERYGII: PERCIFORMES: HAEMULIDAE) FROM THE COASTS OF PERNAMBUCO, NORTH-EASTERN BRAZIL
}

\author{
Alex S. LIRA ${ }^{1 *}$, Andréa P. VIANA ${ }^{1,2}$, Leandro N. EDUARDOํ, Flávia LUCENA-FREDÓU1 ${ }^{1}$, \\ and Thierry FRÉDOU ${ }^{1}$ \\ ${ }^{1}$ Departamento de Pesca e Aquicultura, Universidade Federal Rural de Pernambuco, Recife, Pernambuco, Brazil \\ ${ }^{2}$ Programa de Pós-Graduação em Recursos Aquáticos Continentais (PPG-RACAM), Universidade Federal do Oeste \\ do Pará, Santarém, Pará, Brazil
}

Lira A.S., Viana A.P., Eduardo L.N., Lucena-Fredóu F., Frédou T. 2019. Population structure, size at first sexual maturity, and feeding ecology of Conodon nobilis (Actinopterygii: Perciformes: Haemulidae) from the coasts of Pernambuco, north-eastern Brazil. Acta Ichthyol. Piscat. 49 (4): 389-398.

\begin{abstract}
Background. Although the information on fish ecology and population dynamic are fundamental for fisheries assessment and the development of sustainable management practices, there is still a gap for bycatch species, mainly in tropical coastal areas. The aim of the presently reported study was to describe the feeding habitats, mean length of maturation, and the population structure of Conodon nobilis (Linnaeus, 1758) caught as bycatch of the shrimp trawl fisheries in the south of Pernambuco, north-eastern Brazil.

Materials and methods. Specimens of C. nobilis were collected monthly from August 2011 through July 2012, using an artisanal shrimp outrigger trawler from the local fleet. The population structure was analysed by sex, length, and seasons. Stomachs and gonads were removed and examined to define the length at first maturity $\left(L_{50}\right)$ and the feeding habits of $C$. nobilis in north-eastern Brazil.

Results. A total of 272 specimens were caught. The sex ratio was similar among females and males in the area. The mean size at first maturity $\left(L_{50}\right)$ was estimated as $14.3 \pm 0.65 \mathrm{~cm}$. The diet of the species was mainly based on crustaceans (Penaeidae) and fish, however, it was not observed differences in the diet between juvenile and adults, and climate seasons.

Conclusion. Conodon nobilis was classified as a zoobenthivore species, and showed a higher proportion of individuals caught above the $L_{50}$. The information here provided, combined with other studies in the region, may contribute to the development of improved management strategies to species conservation and exploited marine habitats in northeast Brazil, which is still mostly unknown.
\end{abstract}

Keywords: bycatch, Haemulidae, barred grunt, $L_{50}$, diet

\section{INTRODUCTION}

Bycatch can be defined as the retained catch of nontargeted but commercially valuable species, or species consumed by the crew and local communities, used as bait, or discarded at the port or at sea (Davies et al. 2009, Gilman et al. 2014). Bottom trawling is highly efficient in capturing target species such as shrimp, however, it utilises non-selective gear that is usually associated with high levels of bycatch and (Kelleher 2005). From 2010 to 2014, global discard from bottom trawls was estimated at 4.2 million $t$, comprising $45.5 \%$ of the total annual discard (Pérez Roda et al. 2019). The incidental catch from bottom trawl fishery, combined with the deficiency of fishery management practices, may lead to changes in the marine food web (Rothlisberg and Okey 2007), decline in populations, and increased catch of juveniles and endangered species (Rodrigues-Filho et al. 2015, Silva Júnior et al. 2015, Vieira et al. 2017). However, besides its effects on the aquatic ecosystem, shrimp trawl activity plays an important role in food intake and the source of income of the local communities (Lobo et al. 2010, Tsagarakis et al. 2014, Silva-Júnior et al. 2019).

In the north-eastern part of Brazil, shrimp fishery is predominantly carried out by artisanal boats operating in muddy, shallow coastal waters (Dias Neto 2011). This activity involves more than 100000 persons, about 1700 motorised and 20000 non-motorised boats (Santos 2010), and represents approximately $10 \%$ of the marine total landed fishery resources in the country (Anonymous 2008). Despite the social importance of this fishery in the

" Correspondence: Alex S. LIRA, Laboratório de Estudos de Impactos Antrópicos na Biodiversidade Marinha e Estuarina (BIOIMPACT), Departamento de Pesca e Aquicultura - UFRPE, 52171-900, s/n, Dois Irmãos, Recife, PE, Brazil, phone: +55 81 3320-6514, e-mail: (ASL) alexliraufrpe@outlook.com,(APV) vianaap@yahoo.com.br, (LNE)leandronole@hotmail.com, (FLF)flavia.fredou@ufrpe.br, (TF) thierry.fredou@ufrpe.br. 
region, trawl fisheries operating off Pernambuco are not regulated (Santos 2010), resulting in potential risk for the sustainability and maintenance of the fishing activity. The municipality of Sirinhaém has the highest motorised shrimp fishing fleet among the coastal communities of Pernambuco and penaeids are the most exploited crustaceans (Tischer and Santos 2003).

In Pernambuco, the proportion of fish bycatch and shrimp is $0.39 \div 1$ (fish $\div$ shrimp), which includes the barred grunt, Conodon nobilis (Linnaeus, 1758), as a frequent catch. Despite being an important food source for local fishers, this species is also an important link in the coastal food web, highlighting the need to understand the role of barred grunt and other species in the ecosystem balance (Garcia et al. 2010, Silva-Júnior et al. 2019). Although some information on the population dynamics (e.g., diet, population structure, and size at sexual maturity) of the barred grunt is available (Lopes and Oliveira-Silva 1998, Vasconcelos Filho et al. 2010, Pombo et al. 2014), this essential information does not exist in the region, thereby hampering initiatives of management and conservation of this species.
The aim of the presently reported study was to describe the feeding habitats, mean length of maturation, and the population structure of Conodon nobilis caught as bycatch of the shrimp trawl fisheries in the south of Pernambuco, providing new information that is essential for the development of sustainable management practices.

\section{MATERIALS AND METHODS}

Study area. The study site was the southern coast of Pernambuco, off the city of Sirinhaém, the north-eastern part of Brazil $\left(08^{\circ} 35^{\prime} 57^{\prime \prime}-08^{\circ} 36^{\prime} 57^{\prime \prime} \mathrm{S}, 034^{\circ} 56^{\prime} 58^{\prime \prime}-\right.$ $035^{\circ} 00^{\prime} 48^{\prime \prime} \mathrm{W}$; Fig. 1). This area is located in the Marine Protected Area of Guadalupe (Decreto n ${ }^{\circ} 19.635^{*}$ ).

Data collection. Specimens of Conodon nobilis were collected monthly (August 2011 through July 2012) by accompanying the local fishers (outrigger trawlers). The fishery operated from 1.5 to 3 nautical miles off the coast, mainly between 10 and $20 \mathrm{~m}$ depth, always during the full moon. For each sample (month), three sets of 2 hourly trawls were performed during the daytime, with boat velocity varying between 3 and $7 \mathrm{~km} \cdot \mathrm{h}^{-1}$, using a double

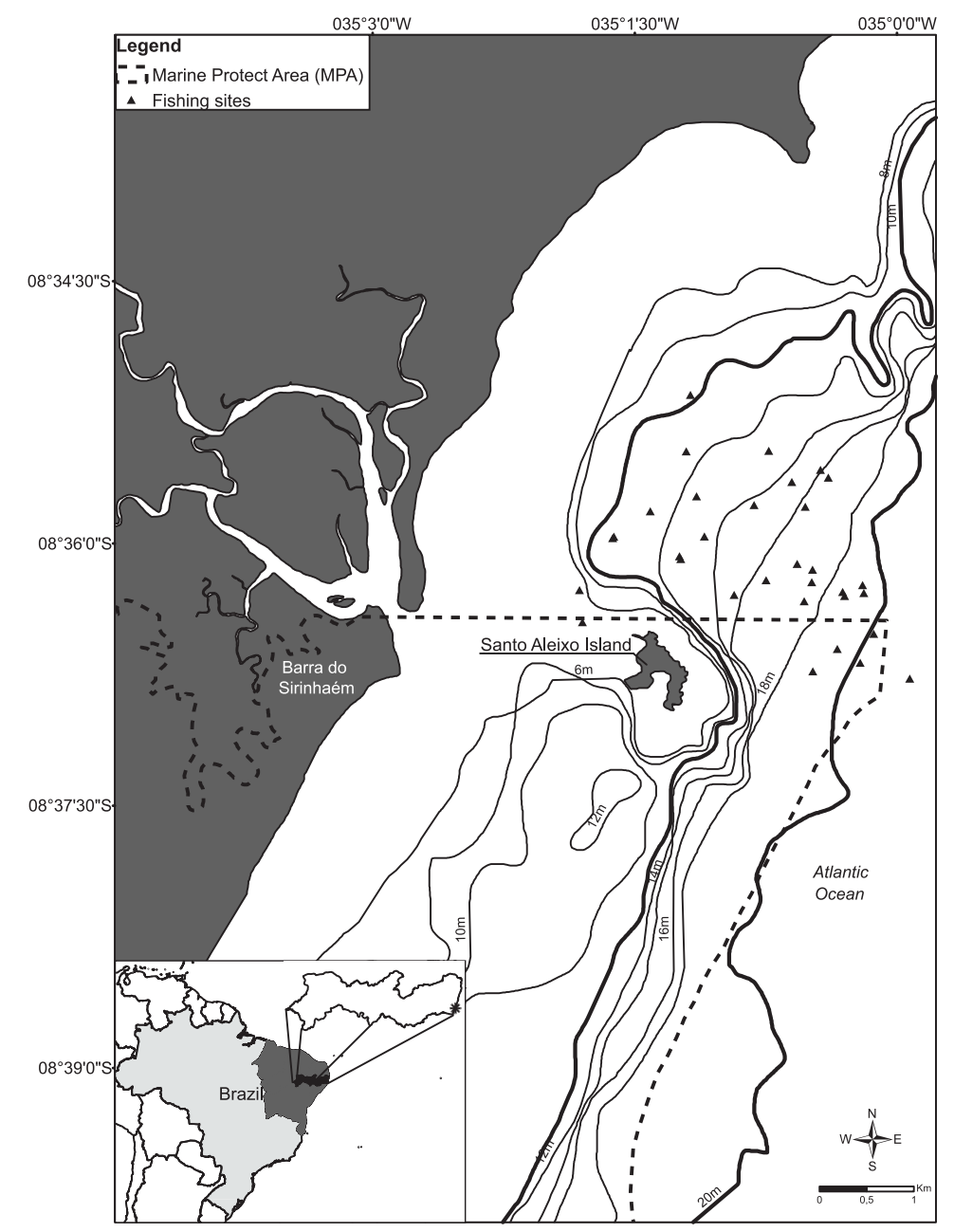

Fig. 1. Study area on the coast of the State of Pernambuco, north-eastern Brazil; black triangles and the dashed line represented fishing sites and the Marine Protect Area of Guadalupe, respectively 
trawl (length: $10 \mathrm{~m}$; horizontal opening: $6.10 \mathrm{~m}$; mesh size body: $30 \mathrm{~mm}$; mesh size codend: $25 \mathrm{~mm}$ ) as the gear. Once collected, the specimens were immediately placed on ice onboard the vessel and were then transported to the laboratory and stored in a freezer $\left(-18^{\circ} \mathrm{C}\right)$ until subsequent analysis. The mean monthly rainfall was obtained from the Agência Pernambucana de Águas e Climas (Anonymous 2017). The sample collection was authorized by federal authorities (Ministério do Meio Ambiente and Instituto Chico Mendes de Conservação da Biodiversidade, permit No. 1922971).

Sample processing. Total length (TL, $\mathrm{cm}$ ) and total weight (TW, g) were recorded for all individuals. Stomachs and gonads were removed for sex and maturation stage determination. The specimens were classified based on the scale proposed by Vazzoler (1996): stages A, immature; $\mathrm{B}$, maturing; $\mathrm{C}$, mature, and $\mathrm{D}$, spawned or resting. Stomachs and gonads were weighed to the nearest 0.01 g. Stomachs were fixed in 10\% formaldehyde within 48 $\mathrm{h}$ and were then conserved in $70 \%$ alcohol. The contents of the individual stomachs were sorted, counted, weighed (g), and identified to the lowest possible taxonomic level.

Data analyses. The population structure was evaluated using the length-frequency distribution considering month and sex. A two-way analysis of variance (ANOVA) was used to determine the differences of mean TL between months and sexes (males, females, and pooled sexes) using transformed data $\log _{10}(\mathrm{x}+1)$ following the assumptions of normality (Kolmogorov-Smirnov test) and homoscedasticity (Bartlett test). Tukey's post-hoc test was used to test the differences of TL among months and sexes (Zar 2009). The determined sex ratios were pooled for each month and size class $(1 \mathrm{~cm})$, were tested for significant deviations from the expected $1 \div 1$ ratio using chi-square $\left(\chi^{2}\right)$ tests. The significant threshold considered was $P<0.05$.

To determine the size at first sexual maturity the percentage of adults by length was calculated and considered as the dependent variable $(y)$ and the TL as the independent variable $(x)$. Individuals with gonads that presented a maturity stage of B, C, or D were classified as adults (Vazzoler 1996). These values were adjusted to a logistic curve by the least-squares approach, to obtain the $L_{50}$ value, using the King (2007) logistic equation:

$$
P_{i}=1 \cdot\left[1+\exp \left(-r\left(L_{t}-L_{50}\right)\right)\right]^{-1}
$$

where, $P_{i}$ is the proportion of adult individuals for each class, $r$ is the slope of the curve, $L_{t}$ is the upper limit of the TL class, and $L_{50}$ is the mean length at first maturation. The 95\% confidence interval was calculated for the $L_{50}$ value. Hotelling's $T^{2}$ test was used to compare the logistic model parameter estimates for males and females (Bernard 1981, Mouine et al. 2012).

The fullness index (FI) was calculated to evaluate the feeding intensity by season and ontogenetic stages to identify periods or stages that might be more sensible for conservation, given the relevance for the development of the species. This index was based on the equation by Hyslop (1980),

$$
\mathrm{FI}=100 \cdot \mathrm{CW} \cdot \mathrm{TW}^{-1}
$$

where $\mathrm{CW}$ is the stomach contents weight and TW is the total weight of the fish. Three parameters described by Hynes (1950) and Hyslop (1980) were used for the qualitative composition of the diet: the frequency of occurrence $\left(\% F_{\mathrm{o}}\right)$, the numerical frequency $(\% N)$, and the weight percentage $(\% W)$. The importance of each prey item was estimated based on the index of relative importance (\%IRI) defined by Pinkas et al. (1971) as

$$
\mathrm{IRI}=\% F_{\mathrm{o}}(\% N+\% W)
$$

expressed in percent

$$
\% \mathrm{IRI}=100 \cdot \mathrm{IRI} \cdot\left(\sum \mathrm{IRI}\right)^{-1}
$$

Due to the poor conservation state, some stomachs were not used for diet analysis.

The diet of $C$. nobilis was evaluated considering the stages of development (adult and juvenile) and climatic seasons. Specimens larger than the length at first sexual maturity obtained here were considered as adults. The seasons were determined based on the monthly mean rainfall: dry (September-December; $38.5 \mathrm{~mm}$ ), dry-rainy transition (January-May; $85.2 \mathrm{~mm}$ ), and rainy season (June-August; $153.2 \mathrm{~mm}$ ). The FI difference between the stages of development, climatic season, and the interaction among then was analysed using a parametric two-way ANOVA, following the necessary assumptions and posthoc test as stated previously.

To assess the degree of similarity in the diet among juveniles and adults, and seasons, multidimensional scaling (MDS) based on a Bray-Curtis similarity matrix was applied for prey abundance $(\% W)$, with the stomachs considered as the sampling unit. Wisconsin double standardisation was applied to the raw data of prey abundance to improve the gradient detection ability of the dissimilarity indices (Bray and Curtis 1957). The differences between life stages (juveniles and adults) and seasons (dry, rainy, and dry-rainy) were tested with a twoway PERMANOVA (Anderson 2001). All analyses were performed using the $\mathrm{R}$ environment ( $\mathrm{R}$ Development Core Team 2018), vegan ${ }^{*}$ and rrcov packages (Todorov and Filzmoser 2009).

\section{RESULTS}

A total of 272 specimens of Conodon nobilis were analysed: $115(42.2 \%)$ were females, 93 (34.1\%) were males, and $64(23.7 \%)$ were immatures that could not be sexed (Table 1). Total length (TL) ranged from 6.6 to 
$27.5 \mathrm{~cm}$ (females 6.6-25.4 cm, males 7.7-27.5 cm), with individuals larger than $13 \mathrm{~cm}$ being dominant (Fig. 2). In general, the sex ratio of females was similar to that of males $(1 \div 0.8)\left(\chi^{2}=2.32, \mathrm{df}=2, P=0.12\right)$, except for the months of March $\left(\chi^{2}=2.38, \mathrm{df}=2, P<0.05\right)$, May $\left(\chi^{2}=\right.$ $2.2, \mathrm{df}=2, P<0.05)$, and December $\left(\chi^{2}=1.8, \mathrm{df}=2, P<\right.$ $0.05)$, and for length class $11-12.1 \mathrm{~cm}\left(\chi^{2}=4.26, \mathrm{df}=2, P\right.$ $<0.05)$, where females dominated. Conodon nobilis was caught throughout the year except in July.

The TL of the individuals was significantly different among months $\left(F_{(10,52)}=2.572 ; P<0.05\right)$. The largest individuals were caught in August, November, and May, whereas the smallest were captured in March (Tukey, $P$ $<0.05$ ) (Fig. 3). However, no statistical differences in TL (overall $\left(F_{(1,52)}=0.226 ; P=0.64\right)$ and monthly $\left(F_{(10,52)}\right.$

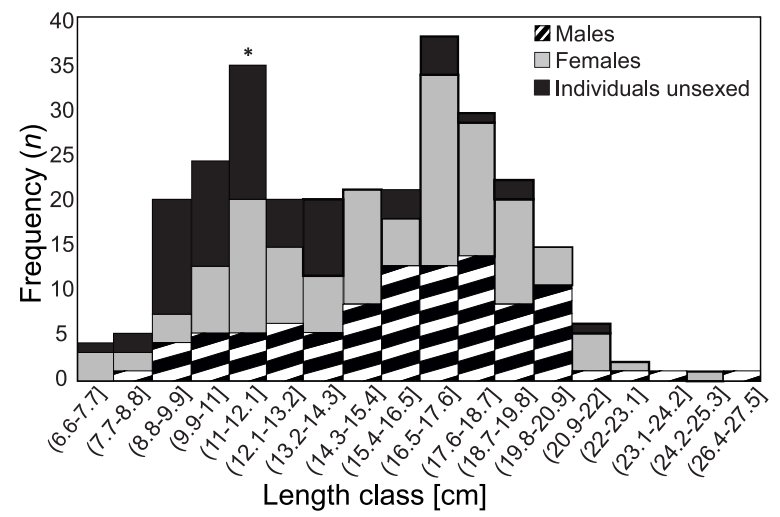

Fig. 2. Absolute frequency distribution per length classes of males, females, and unsexed individuals of Conodon nobilis, captured in the period from August 2011 through July 2012, off the coast of State of Pernambuco, north-eastern Brazil; significant differences of sex ratios between males and females to length classes are represented by an asterisk $(*)$
$=0.448 ; P>0.91))$ were found between females $(15.27 \pm$ $3.74 \mathrm{~cm}$; mean $\pm \mathrm{SD})$ and males $(16.1 \pm 3.54 \mathrm{~cm})$.

No significant differences in TL at first maturity $\left(L_{50}\right)$ for $C$. nobilis were found between sexes (Hotelling's $T^{2}$, $\left.T^{2}=3.82, P=0.15\right)$. Therefore, data were pooled and the $L_{50}$ estimated for combined sexes was $14.3 \pm 0.65 \mathrm{~cm}$ (Fig. 4). The smallest adult individual had a TL of $9.6 \mathrm{~cm}$, whereas all those with TL above $17.4 \mathrm{~cm}$ were adults (Fig. 4). A greater proportion of the catch contained individuals above the $L_{50}$ value (Fig. 2).

Overall, 165 stomachs were analysed and 123 (75\%) contained food contents. The values of the fullness index (FI) of the juveniles (2.7) was similar to that of the adults (2.5) $\left(F_{(1,162)}=1.371 ; P=0.19\right)$. Higher FI values were observed during the dry season $\left(F_{(2,162)}=7.987 ; P<0.05\right)$

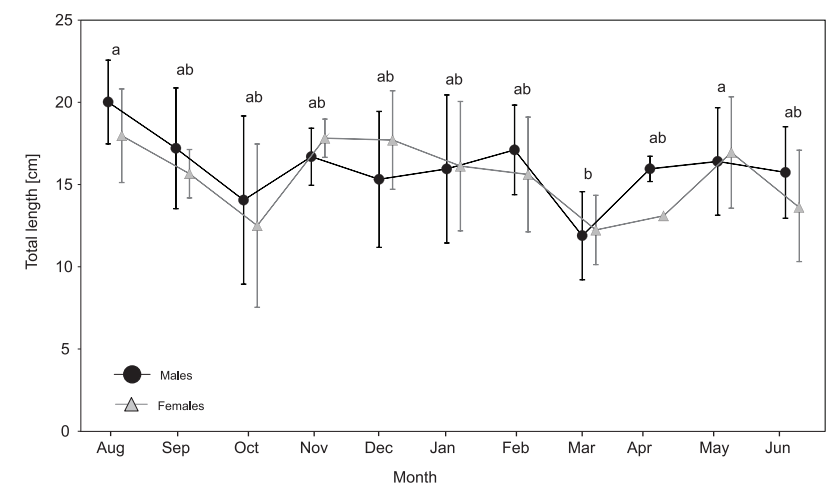

Fig. 3. Monthly mean $( \pm \mathrm{SD})$ in total length (TL) (cm) of males and females of Conodon nobilis captured from August 2011 through July 2012, off the coast of the State of Pernambuco, north-eastern Brazil; different letters indicate significant differences in the mean TL between months

Table 1

Capture composition of the specimens of Conodon nobilis captured between August 2011 to July 2012, off Sirinhaém, State of Pernambuco, north-eastern Brazil

\begin{tabular}{|c|c|c|c|c|c|c|c|c|c|c|c|}
\hline \multirow{3}{*}{ Month } & \multirow{3}{*}{ SDM } & \multirow{3}{*}{ Season } & \multicolumn{3}{|c|}{ All individuals } & \multicolumn{3}{|c|}{ Female } & \multicolumn{3}{|c|}{ Male } \\
\hline & & & \multirow{2}{*}{$N$} & $\mathrm{TL}[\mathrm{cm}]$ & \multirow{2}{*}{$n$} & \multirow{2}{*}{$N$} & $\mathrm{TL}[\mathrm{cm}]$ & \multirow{2}{*}{$n$} & \multirow{2}{*}{$N$} & $\mathrm{TL}[\mathrm{cm}]$ & \multirow{2}{*}{$n$} \\
\hline & & & & $($ mean $\pm \mathrm{SD})$ & & & $($ mean $\pm \mathrm{SD})$ & & & $($ mean $\pm \mathrm{SD})$ & \\
\hline Jan & \multirow{4}{*}{ S } & \multirow{5}{*}{$\begin{array}{l}\text { Dry-rainy } \\
\text { transition }\end{array}$} & 13 & $15.88 \pm 4.09$ & 13 & 3 & $16.00 \pm 3.91$ & 3 & 7 & $15.83 \pm 4.47$ & 7 \\
\hline Feb & & & 49 & $16.22 \pm 3.16$ & 30 & 19 & $15.49 \pm 3.46$ & 9 & 18 & $16.98 \pm 2.70$ & 3 \\
\hline Mar & & & 32 & $12.06 \pm 2.15$ & 30 & 13 & $12.15 \pm 2.09$ & 11 & 4 & $11.80 \pm 2.66$ & 4 \\
\hline Apr & & & 5 & $15.13 \pm 1.55$ & 5 & 1 & $13.00 \pm 0.00$ & 1 & 3 & $15.83 \pm 0.76$ & 3 \\
\hline May & S & & 58 & $16.63 \pm 3.30$ & 26 & 33 & $16.82 \pm 3.36$ & 13 & 18 & $16.28 \pm 3.24$ & 10 \\
\hline Jun & & \multirow{3}{*}{ Rainy } & 28 & $14.69 \pm 3.08$ & 12 & 11 & $13.52 \pm 3.19$ & 4 & 14 & $15.61 \pm 2.76$ & 6 \\
\hline Jul & & & \multicolumn{9}{|c|}{ Conodon nobilis has not occurred } \\
\hline Aug & & & 12 & $19.19 \pm 2.65$ & 5 & 3 & $17.83 \pm 2.82$ & 1 & 6 & $19.87 \pm 2.52$ & 1 \\
\hline Sep & & \multirow{4}{*}{ Dry } & 13 & $16.48 \pm 3.01$ & 7 & 5 & $15.54 \pm 1.46$ & 4 & 8 & $17.08 \pm 3.64$ & 3 \\
\hline Oct & & & 38 & $13.08 \pm 4.94$ & 25 & 13 & $12.41 \pm 4.93$ & 7 & 10 & $13.95 \pm 5.07$ & 3 \\
\hline Nov & & & 13 & $17.31 \pm 1.37$ & 1 & 6 & $17.68 \pm 1.15$ & 0 & 3 & $16.57 \pm 1.72$ & 0 \\
\hline Dec & $\mathrm{S}$ & & 11 & $17.10 \pm 3.12$ & 11 & 8 & $17.58 \pm 2.97$ & 8 & 2 & $15.20 \pm 4.10$ & 2 \\
\hline
\end{tabular}

$\mathrm{SDM}=$ significance of differences of sex ratios between months, $\mathrm{S}=$ significant, $\mathrm{TL}=$ total length of fish, $N=$ number of fish examined, $n$ $=$ number of stomachs analysed, $\mathrm{SD}=$ standard deviation. 
(Fig. 5). Juveniles and adults presented similar FI values among seasons $\left(F_{(2,162)}=2.808 ; P=0.06\right)$. The diet of $C$. nobilis, which was similar between juveniles and adults, was based on 19 food items, with shrimps (Penaeidae) $(\%$ IRI $=79.8)$ and Actinopterygii $(\%$ IRI $=16.2)$ being the most important components (Table 2).

The diet composition from the MDS ordination displayed a similar pattern for juveniles and adults because they mainly fed on shrimps and ray-finned fishes (Fig. 6). No significant differences between the diets of juveniles and adults (Pseudo- $F_{(1,121)}=1.06 ; P=0.31$ ), seasons (Pseudo- $\left.F_{(2,121)}=1.61 ; P=0.16\right)$, and their interactions (Pseudo- $\left.F_{(2,121)}=1.83 ; P=0.08\right)$ were observed.

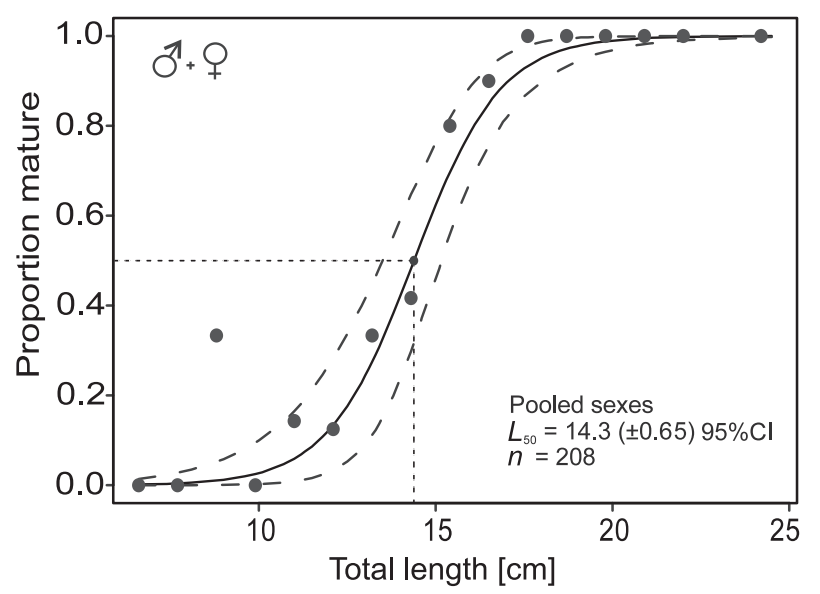

Fig. 4. Length at first maturity $\left(L_{50}\right)$ for Conodon nobilis captured between August 2011 and July 2012, off Sirinhaém, State of Pernambuco, north-eastern Brazil

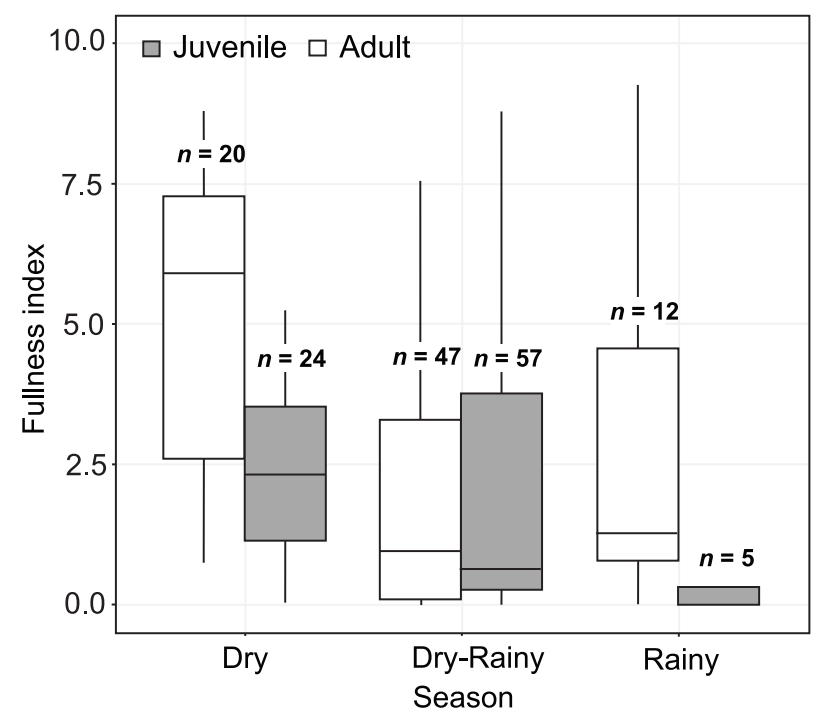

Fig. 5. Boxplot of the fullness index (FI) value for development stage and season of Conodon nobilis captured between August 2011 and July 2012, off Sirinhaém, State of Pernambuco, north-eastern Brazil; grey and white boxes represent juveniles and adults, respectively

\section{DISCUSSION}

Fishing activities directly affect demersal fish communities via the removal of species (target and nontarget) and habitat modifications (Eduardo et al. 2018a). Trawling activity may promote changes to the seabed, such as sediment resuspension and the injury or death of a wide range of benthic organisms (Ortega et al. 2018). Moreover, untargeted catches lead to adverse effects on population parameters and species composition (Shephard et al. 2010, Hiddink et al. 2011), thus changing the ecological interaction between species, which might affect the sustainability of the fishery. This is the case of Conodon nobilis caught as a bycatch in the shrimp fishery in Brazil.

Size differences between months may be related to the level of exploitation in the area, the ecological characteristics of each region, and the differential selectivity of the fishing gear (Frédou et al. 2009). Along the southern coast of Pernambuco, the maximum lengths recorded $(27.5 \mathrm{~cm})$ for $C$. nobilis were greater than those recorded for the same species in other areas, e.g., 15 $\mathrm{cm}$ in Caraguatatuba Bay, São Paulo (Brazil) (Pombo et al. 2014), $12 \mathrm{~cm}$ in Rio Grande do Norte (Brazil) (Garcia et al. 2010), and $26 \mathrm{~cm}$ in the Gulf of Salamanca (Colombia) (Garcia et al. 1998). Although the results of the presently reported study may be hampered by the selectivity of the fishing gear, based on the habitat of the species (shallow muddy bottoms) and the $L_{\max }$ reported (33.6 cm TL, Cervigón et al. 1992), which is near to the range of individuals caught in the presently reported study (6.6 to $27.5 \mathrm{~cm} \mathrm{TL}$, including juveniles and adults), we assumed that our sampling adequately covered the size and behaviour of the species, and the parameters provided here are representative of the $C$. nobilis population in northeast Brazil.

Females and males presented similar abundance. The sex ratio provides important information regarding the relation between individuals and the environment and the population situation of each species (Conover and Voorhees 1990). It also provides basic information to assess the reproductive potential of the species and to estimate the size of the population stock (Stratoudakis et al. 2006, Cerviño 2014, Farley et al. 2014). This scenario is directly influenced by the reproductive strategy of the species, environmental variations of the ecosystems (Murua et al. 2003, Ospina-Álvarez and Piferrer 2008), and fishing (Robinson et al. 2017).

Conodon nobilis is a benthic carnivorous predator with a short intestine and large stomach that has a great expansion capacity (Garcia et al. 2010). Trawls mainly target demersal organisms (McHugh et al. 2017) and species that forage near the bottom (Pombo et al. 2014), such as $C$. nobilis, which is directly affected by such trawling activity. The feeding intensity, described as the fullness index (FI), may be greatly influenced by the availability and type of prey, length range of the predator, reproductive season, and daily variation (Pereira et al. 2016, Perelman et al. 2017). In the presently reported study, high FI values were found, indicating an intense use of the environment as a feeding area. 
Table 2

Principal prey items characteristics of the Conodon nobilis captured between August 2011 to July 2012, off Sirinhaém, State of Pernambuco, north-eastern Brazil

\begin{tabular}{|c|c|c|c|c|c|c|c|c|c|c|c|c|c|}
\hline & \multirow{2}{*}{ Prey item } & \multicolumn{4}{|c|}{ Overall } & \multicolumn{4}{|c|}{$\begin{array}{c}\text { Juveniles }(<14.3 \mathrm{~cm}) \\
\qquad N=61\end{array}$} & \multicolumn{4}{|c|}{$\begin{array}{c}\text { Adults }(\geq 14.3 \mathrm{~cm}) \\
N=62\end{array}$} \\
\hline & & $\% F_{\mathrm{o}}$ & $\% N$ & $\% P$ & $\%$ IRI & $\% F_{\mathrm{o}}$ & $\% N$ & $\% P$ & $\%$ IRI & $\% F_{\mathrm{o}}$ & $\% N$ & $\% P$ & $\%$ IRI \\
\hline \multirow{9}{*}{ 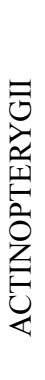 } & Clupeiformes & 1.42 & 0.68 & 0.50 & 0.02 & 0.79 & 0.55 & 0.68 & 0.01 & 2.70 & 1.28 & 0.28 & 0.06 \\
\hline & Engraulidae & 0.71 & 0.23 & 0.99 & 0.01 & 0.79 & 0.27 & 1.79 & 0.02 & - & - & - & - \\
\hline & Polynemidae & 0.71 & 0.23 & 0.29 & $<0.01$ & 0.79 & 0.27 & 0.53 & 0.01 & - & - & - & - \\
\hline & Anchoa spp. & 1.42 & 0.45 & 2.38 & 0.05 & 0.79 & 0.27 & 3.28 & 0.04 & 2.70 & 1.28 & 1.28 & 0.09 \\
\hline & Chirocentrodon bleekerianus & 2.13 & 0.68 & 6.79 & 0.18 & - & - & - & - & 8.11 & 3.85 & 15.08 & 2.04 \\
\hline & Odontognathus mucronatus & 0.71 & 0.23 & 1.21 & 0.01 & - & - & - & - & 2.70 & 1.28 & 2.68 & 0.14 \\
\hline & Paralonchurus brasiliensis & 3.55 & 1.36 & 1.66 & 0.12 & 2.38 & 0.82 & 0.61 & 0.04 & 5.41 & 3.85 & 2.93 & 0.49 \\
\hline & Stellifer spp. & 0.71 & 0.23 & 0.49 & 0.01 & - & - & - & - & 2.70 & 1.28 & 1.10 & 0.09 \\
\hline & Symphurus spp. & 4.96 & 2.26 & 0.68 & 0.16 & 4.76 & 2.20 & 1.10 & 0.20 & 2.70 & 2.56 & 0.17 & 0.10 \\
\hline \multirow{6}{*}{ 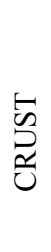 } & Actinopterygii not identified & 58.16 & 9.28 & 15.61 & 16.23 & 54.76 & 9.07 & 18.42 & 19.01 & 35.14 & 10.26 & 12.17 & 10.49 \\
\hline & Brachyura & 0.71 & - & 0.07 & $<0.01$ & 0.79 & - & 0.12 & 0.00 & - & - & - & - \\
\hline & Penaeidae & 56.03 & 73.08 & 53.95 & 79.82 & 47.62 & 74.18 & 52.21 & 76.03 & 51.35 & 67.95 & 56.07 & 84.80 \\
\hline & Palaemonidae & 0.71 & 0.45 & 1.48 & 0.02 & 0.79 & 0.55 & 2.69 & 0.03 & - & - & - & - \\
\hline & Xiphopenaeus kroyeri & 4.96 & 7.69 & 6.86 & 0.81 & 4.76 & 9.07 & 9.45 & 1.11 & 2.70 & 1.28 & 3.71 & 0.18 \\
\hline & Isopoda & 1.42 & 0.45 & 0.04 & 0.01 & 1.59 & 0.55 & 0.08 & 0.01 & - & - & - & - \\
\hline ML & Squid & 0.71 & 0.45 & 0.42 & 0.01 & 0.79 & 0.55 & 0.77 & 0.01 & - & - & - & - \\
\hline \multirow{4}{*}{ OT } & Aquatics plants & 1.42 & 2.04 & 0.13 & 0.03 & 0.79 & 1.65 & 0.17 & 0.02 & 2.70 & 3.85 & 0.07 & 0.14 \\
\hline & Detritus & 2.84 & - & 0.08 & $<0.01$ & 2.38 & - & 0.12 & $<0.01$ & 2.70 & - & 0.04 & $<0.01$ \\
\hline & Undefined organic matter & 39.01 & - & 5.72 & 2.50 & 34.13 & - & 7.98 & 3.44 & 32.43 & - & 2.97 & 1.28 \\
\hline & Platyhelminthes & 0.71 & 0.23 & 0.65 & 0.01 & - & - & - & - & 2.70 & 1.28 & 1.45 & 0.10 \\
\hline
\end{tabular}

CRUST $=$ Crustacea, $\mathrm{ML}=$ Mollusca, OT $=$ other; $\% F_{0}=$ frequency of occurrence, $N=$ number of fish examined, $\% N=$ numerical frequency, $\% \mathrm{IRI}=$ percentage index of relative importance.

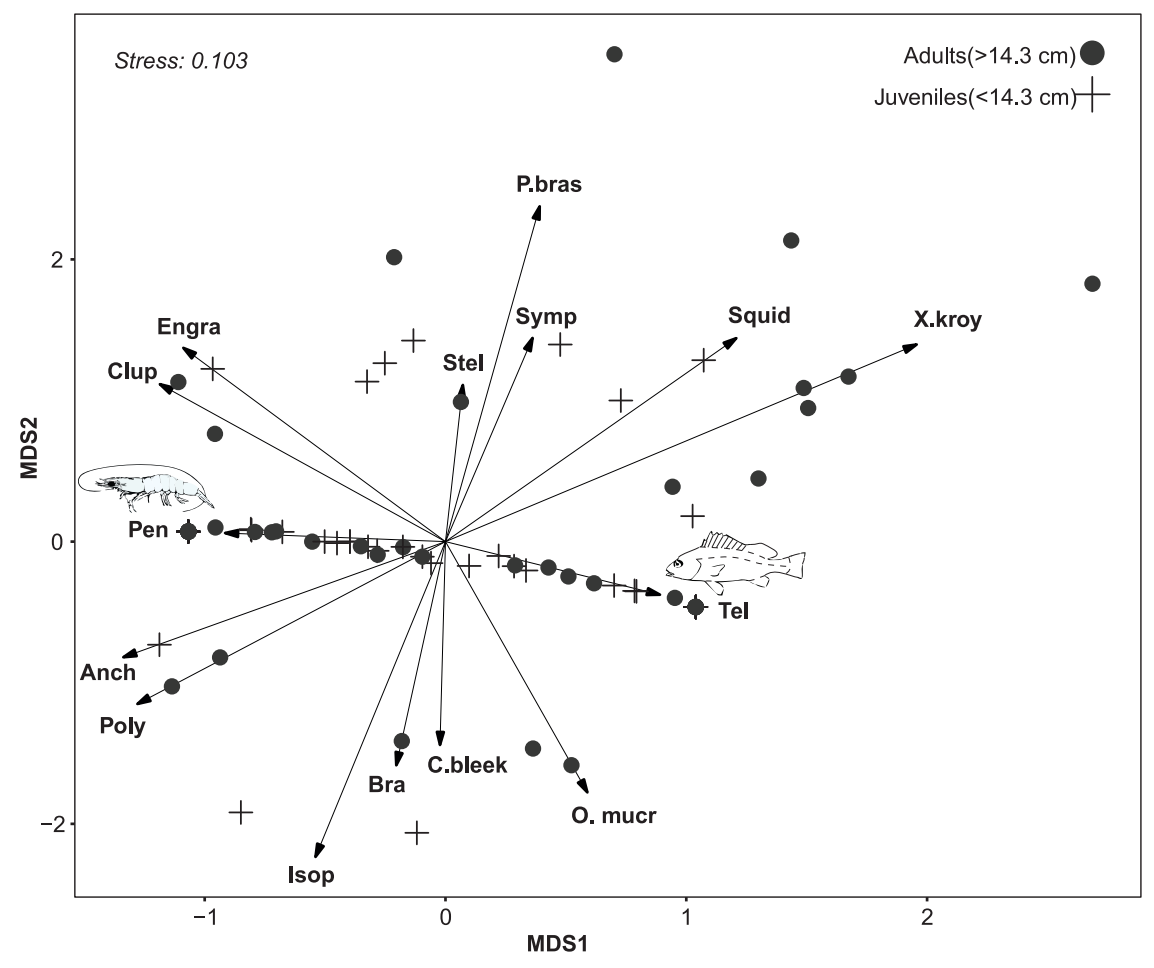

Fig. 6. MDS plot of the feed composition of Conodon nobilis off Sirinhaém, State of Pernambuco, north-eastern Brazil; abbreviations, Clup = Clupeiformes, Engra = Engraulidae, Stel = Stellifer spp., Poly = Polynemidae, Anch = Anchoa spp., C.bleek $=$ Chirocentrodon bleekerianus, O.mucr $=$ Odontongathus mucronatus, P.bras $=$ Paralonchurus brasilienses, Symp = Symphurus spp., Tel = ray-finned fishes not identified, Bra = Brachyura, Pen = Penaeidae, X.kroy = Xiphopenaeus kroyeri, Isop = Isopoda, Squid $=$ squid 
Previous studies on the feeding habits of this species (Lopes and Oliveira-Silva 1998, Vasconcelos Filho et al. 2010) in Itamaracá Island, northeast part of Brazil and Caraguatatuba Bight, south-eastern Brazil (Pombo et al. 2014) have shown that their main prey items are crustaceans. Similar results were observed in the presently reported study, with $C$. nobilis classified as a zoobenthivore, feeding on crustaceans, mainly shrimps of the family Penaeidae. The occurrence of aquatic plants, detritus, and Platyhelminthes detected in the stomachs of carnivorous species are probably ingested accidentally (Feitosa et al. 2002). The availability and consequently the aggregation of prey can strongly influence the species feeding habitat patterns (Lawton and Pratchett 2012, Jacobson et al. 2018), causing them to feed on prey that has the highest availability.

The presently reported study provides, to the best of our knowledge, the first estimation of the mean length at first maturity $\left(L_{50}\right)$ for $C$. nobilis. The size at first sexual maturity is fundamental information in fishery science for the management of single species assessment, and is frequently used as a reference for evaluating the catch of juveniles in fisheries worldwide (Wolff et al. 2015, Lappalainen et al. 2016, Lucena Frédou et al. 2016, Tirado-Ibarra et al. 2018). In general, the trawling bycatch is mainly composed of small individuals, usually juveniles (Silva Júnior et al. 2015). However, for C. nobilis, a higher proportion of individuals above the $L_{50}$ value were found, thus the majority of the harvested individuals might have been able to reproduce and contribute to population renewal (Eduardo et al. 2018b). This represents a good indicator of the sustainability of the stock. However, considering that $C$. nobilis is a bycatch species, fishery performance indicators (Anderson et al. 2015) are considered quite promising in evaluating multispecies fisheries, such as shrimp trawling. The monitoring over time of basic indicators of target and non-target species, which considers population parameters such as size, weight, and maturity, are also important tools to evaluate the sustainability of a fishery (Wells et al. 2008, Jarić et al. 2016, Plazas-Gómez et al. 2018) as well as for the application of different management strategies such as area and time closures and Bycatch Reduce Devices (BRD) (Arellano-Torres et al. 2006, McHugh et al. 2017, Pérez Roda et al. 2019).

The shrimp fishery off the coast of Pernambuco, which has a multispecies capture, is under no fishing regulations or landing control, which goes against the Code of Conduct for Responsible Fisheries (CCRF) (Anonymous 1995). The CCRF recommends that the entire catch should be managed in an ecologically sustainable manner; thus, a regulation for this area should be established considering the main species involved (target and bycatch). Previous studies in the region have shown that the bulk of the catch of the shrimp fishery in Pernambuco shares the same feeding ground and season of reproduction (e.g., between October and March) (Lopes et al. 2014, 2017, Silva et al. 2015, 2016, 2018, Silva Júnior et al. 2015, Eduardo et al. 2018b, Peixoto et al. 2018) and a closed season could be established during the austral summer. In addition, the application of BRD (e.g., fisheye, grid and square mesh) used to exclude fish and other small bycatch from the trawl (Broadhurst 2000, Eayrs 2007, Larsen et al. 2017) might be a good conservation tool. Some initiatives that are limited by the lack of information occur in this region, such as the experimental use of bycatch reduction technologies (Anonymous 2018) and Marine Protected Areas (e.g., APA Guadalupe), which still has no management plan. The results of the presently reported study combined with other available information in the area will contribute to the development of improved management policies, considering the ecosystem approach to fisheries for improving species conservation and exploited marine habitats in Pernambuco, which is still mostly unknown.

\section{ACKNOWLEDGEMENTS}

We are grateful to the Conselho Nacional de Desenvolvimento Científico e Tecnologico (CNPq) for providing a research grant to Flávia Lucena Frédou. This work was carried out under the National Institute of Science and Technology in Tropical Marine Environments (INCT-AmbTropic) (CNPq process \#565054/2010-4) and as also partially funded by the Fundação de Ciência e Tecnologia do Estado de Pernambuco (FACEPE). We are also grateful for fishermen and members of the BIOIMPACT Laboratory for field assistance.

\section{REFERENCES}

Anderson J.L., Anderson C.M., Chu J., Meredith J., Asche F., Sylvia G., Smith M.D., Anggraeni D., Arthur R., Guttormsen A., McCluney J.K., Ward T., Akpalu W., Eggert H., Flores J., Freeman M.A., Holland D.S., Knapp G., Kobayashi M., Larkin S., MacLauchlin K., Schnier K., Soboil M., Tveteras S., Uchida H., Valderrama D. 2015. The fishery performance indicators: A management tool for triple bottom line outcomes. PLoS ONE 10 (5): e0122809. DOI: 10.1371/journal.pone.0122809

Anderson M.J. 2001. A new method for non-parametric multivariate analysis of variance. Austral Ecology 26 (1): 32-46. DOI: 10.1111/j.1442-9993.2001.01070.pp.x

Anonymous 1995. Code of conduct for responsible fisheries. FAO, Rome.

Anonymous 2008. Estatística da pesca 2007, Grandes regiões e unidades da federação. [Fishery statistics 2007, major regions and federation units.] Ibama, Brasília DF, Brazil. [In Portuguese.]

Anonymous 2017. Monitoramento Pluviométrico. [Rain monitoring.] Agência Pernambucana de Águas e Clima. [Accessed 2 Feb 2017]. [In Portuguese.] http:// www.apac.pe.gov.br/meteorologia/monitoramentopluvio.php

Anonymous 2018. Reduction of environmental impact from tropical shrimp trawling through the introduction of bycatch reduction technologies and change of management. REBYC and FAO, Rome.

Arellano-Torres A., Pérez-Castañeda R., Defeo O. 2006. Effects of a fishing gear on an artisanal multispecific 
penaeid fishery in a coastal lagoon of Mexico: Mesh size, selectivity and management implications. Fisheries Management and Ecology 13 (5): 309-317. DOI: $10.1111 / \mathrm{j} .1365-2400.2006 .00507 . \mathrm{x}$

Bernard D.R. 1981. Multivariate analysis as a means sf comparing growth in fish. Canadian Journal of Fisheries and Aquatic Sciences 38 (2): 233-236. DOI: 10.1139/f81-030

Bray J.R., Curtis J.T. 1957. An ordination of the upland forest communities of southern Wisconsin. Ecological Monographs 27 (4): 325-349. DOI: 10.2307/1942268

Broadhurst M.K. 2000. Modifications to reduce bycatch in prawn trawls: A review and framework for development. Reviews in Fish Biology and Fisheries 10 (1): 27-60. DOI: 10.1023/A:1008936820089

Cervigón F., Cipriani R., Fischer W., Garibaldi L., Hendrickx M., Lemus A., Márquez R., Poutiers J., Robaina G., Rodriguez B. 1992. Guía de campo de las especies comerciales marinas y de aguas salobres de la costa septentrional de Sur América. Fichas FAO de identificación de especies para los fines de la pesca. FAO, Rome.

Cerviño S. 2014. Estimating growth from sex ratio-atlength data in species with sexual size dimorphism. Fisheries Research 160: 112-119. DOI: 10.1016/j. fishres.2013.11.010

Conover D.O., Van Voorhees D.A. 1990. Evolution of a balanced sex ratio by frequency-dependent selection in a fish. Science 250 (4987): 1556-1558. DOI: 10.1126/ science. 250.4987 .1556

Davies R.W.D., Cripps S.J., Nickson A., Porter G. 2009. Defining and estimating global marine fisheries bycatch. Marine Policy 33 (4): 661-672. DOI: 10.1016/j.marpol.2009.01.003

Dias Neto J. 2011. Proposta de plano nacional de gestão para o uso sustentável de camarões marinhos no Brasil. [A proposal for a national management plan for the sustainable use of sea shrimp in Brazil.] Ibama, Brasília, DF, Brazil. [In Portuguese.]

Eayrs S. 2007. A guide to bycatch reduction in tropical shrimp-trawl fisheries. Revised edition. FAO, Rome.

Eduardo L.N., Frédou T., Lira A.S., Ferreira B.P., Bertrand A., Ménard F., Frédou F.L. 2018a. Identifying key habitat and spatial patterns of fish biodiversity in the tropical Brazilian continental shelf. Continental Shelf Research 166: 108-118. DOI: 10.1016/j.csr.2018.07.002

Eduardo L.N., Lira A.S., Frédou T., Lucena-Frédou F. 2018b. Population structure and reproductive biology of Haemulopsis corvinaeformis (Perciformes, Haemulidae) in the south coast of Pernambuco, northeastern Brazil. Iheringia. Série Zoologia 108: 1-8. DOI: 10.1590/1678-4766e2018007

Farley J.H., Eveson J.P., Davis T.L.O., Andamari R., Proctor C.H., Nugraha B., Davies C.R. 2014. Demographic structure, sex ratio and growth rates of southern bluefin tuna (Thunnus maccoyii) on the spawning ground. PLoS ONE 9 (5): e96392. DOI: 10.1371/journal.pone.0096392
Feitosa C.V., Pimenta D.A.S., de Araújo M.E. 2002. Hábito alimentar de espécies de peixes na área de influência do emissário oceânico de Fortaleza, Ceará, Brasil. [Feeding habits of some fish species that live under influence of the sewerage disposal system of Fortaleza, Ceará State, Brazil. Arquivos de Ciência do Mar 35: 91-95. [In Portuguese.]

Frédou T., Ferreira B.P., Letourneur Y. 2009. Assessing the stocks of the primary snappers caught in Northeastern Brazilian Reef Systems . 2-A multi-fleet age-structured approach. Fisheries Research 99 (2): 97-105. DOI: 10.1016/j.fishres.2009.05.009

Garcia C.B., Duarte L.O., Sandoval N., von Schiller D., Melo G., Navajas P. 1998. Length-weight relationships of demersal fishes from the Gulf of Salamanca, Colombia. Naga, the ICLARM Quarterly 21 (3): 34-36.

Garcia J.jr., Mendes L.F., Sampaio C.L.S., Lins J.E. 2010. Biodiversidade marinha da Bacia Potiguar: Ictiofauna. [Marine biodiversity of the Potiguar Basin: Ichthyofauna.] Serie Livros 38. Museu Nacional, Rio de Janeiro, Brasil. [In Portuguese.]

Gilman E., Passfield K., Nakamura K. 2014. Performance of regional fisheries management organizations: Ecosystem-based governance of bycatch and discards. Fish and Fisheries 15 (2): 327-351. DOI: 10.1111/ faf. 12021

Hiddink J.G., Johnson A.F., Kingham R., Hinz H. 2011. Could our fisheries be more productive? Indirect negative effects of bottom trawl fisheries on fish condition. Journal of Applied Ecology 48 (6): 14411449. DOI: $10.1111 / j .1365-2664.2011 .02036 . x$

Hynes H.B.N. 1950. The food of fresh-water sticklebacks (Gasterosteus aculeatus and Pygosteus pungitius), with a review of methods used in studies of the food of fishes. Journal of Animal Ecology 19 (1): 36-58. DOI: $10.2307 / 1570$

Hyslop E.J. 1980. Stomach contents analysis-A review of methods and their application. Journal of Fish Biology 17 (4): 411-429. DOI: 10.1111/j.10958649.1980.tb02775.x

Jacobson P., GårdmarkA., Östergren J., Casini M., Huss M. 2018. Size-dependent prey availability affects diet and performance of predatory fish at sea: A case study of Atlantic salmon. Ecosphere 9 (1): e02081. DOI: $10.1002 /$ ecs2.2081

Jarić I., Smederevac-Lalić M., Jovičić K., Jaćimović M., Cvijanović G., Lenhardt M., Kalauzi A. 2016. Indicators of unsustainable fishery in the middle Danube. Ecology of Freshwater Fish 25 (1): 86-98. DOI: $10.1111 /$ eff.12193

Kelleher K. 2005. Discards in the world's marine fisheries. An update. FAO Technical Paper No 131. FAO, Rome.

King M. 2007. Fisheries biology, assessment and management. 2nd edn. Blackwell Publishing, Oxford, UK. DOI: 10.1002/9781118688038

Lappalainen A., Saks L., Šuštar M., Heikinheimo O., Jürgens K., Kokkonen E., Kurkilahti M., Verliin A., Vetemaa M. 2016. Length at maturity 
as a potential indicator of fishing pressure effects on coastal pikeperch (Sander lucioperca) stocks in the northern Baltic Sea. Fisheries Research 174: 47-57. DOI: 10.1016/j.fishres.2015.08.013

Larsen R.B., Herrmann B., Sistiaga M., Brinkhof J., Tatone I., Langård L. 2017. Performance of the Nordmøre grid in shrimp trawling and potential effects of guiding funnel length and light stimulation. Marine and Coastal Fisheries 9 (1): 479-492. DOI: 10.1080/19425120.2017.1360421

Lawton R.J., Pratchett M.S. 2012. Influence of dietary specialization and resource availability on geographical variation in abundance of butterflyfish. Ecology and Evolution 2 (7): 1347-1361. DOI: 10.1002/ece3.253

Lobo A.S., Balmford A., Arthur R., Manica A. 2010. Commercializing bycatch can push a fishery beyond economic extinction. Conservation Letters 3 (4): $277-$ 285. DOI: 10.1111/j.1755-263X.2010.00117.x

Lopes D.F.C., Lucena Frédou F., Silva E.F.B., Calazans N., Peixoto S. 2017. Reproductive cycle of seabob shrimp Xiphopenaeus kroyeri (Crustacea, Penaeidea) from the northeast coast of Brazil. Invertebrate Reproduction and Development 61 (3): 137-141. DOI: $10.1080 / 07924259.2017 .1311951$

Lopes D.F.C., Peixoto S., Silva E.F.B., Lucena-Frédou F. 2014. Population biology of seabob-shrimp Xiphopenaeus kroyeri (Heller, 1862) captured on the south coast of Pernambuco State, northeastern Brazil. Brazilian Journal of Oceanography 62 (4): 331-340. DOI: 10.1590/S1679-87592014079706204

Lopes P.R.D., Oliveira-Silva J.T. 1998. Nota sobre a alimentação de Conodon nobilis (Linnaeus) e Polydactylus virginicus (Linnaeus) (Actinopterygii: Haemulidae e Polynemidae) na Praia de Jaguaribe (Ilha de Itamaracá), Estado de Pernambuco. [A note on the feeding of Conodon nobilis (Linnaeus) and Polydactylus virginicus (Linnaeus) (Actinopterygii: Haemulidae and Polynemidae) in the Jaguaribe Beach (Itamaracá Island), State of Pernambuco.] Bioikos 12 (2): 53-58. [In Portuguese.]

Lucena Frédou F., Frédou T., Gaertner D., Kell L., Potier M., Bach P., Travassos P., Hazin F., Ménard F. 2016. Life history traits and fishery patterns of teleosts caught by the tuna longline fishery in the South Atlantic and Indian Oceans. Fisheries Research 179: 308-321. DOI: 10.1016/j.fishres.2016.03.013

McHugh M.J., Broadhurst M.K., Sterling D.J. 2017. Choosing anterior-gear modifications to reduce the global environmental impacts of penaeid trawls. Reviews in Fish Biology and Fisheries 27 (1): 111134. DOI: 10.1007/s11160-016-9459-5

Mouine N., Francour P., Ktari M.H., ChakrounMarzouk N. 2012. Reproductive biology of four Diplodus species Diplodus vulgaris, D. annularis, $D$. sargus sargus and D. puntazzo (Sparidae) in the Gulf of Tunis (central Mediterranean). Journal of the Marine Biological Association of the United Kingdom 92 (3): 623-631. DOI: 10.1017/ S0025315411000798
Murua H., Kraus G., Saborido-Rey F., Witthames P.R., Thorsen A., Junquera S. 2003. Procedures to estimate fecundity of marine fish species in relation to their reproductive strategy. Journal of Northwest Atlantic Fishery Science 33: 33-54.

Ortega I., Colling L.A., Dumont L.F.C. 2018. Response of soft-bottom macrobenthic assemblages to artisanal trawling fisheries in a subtropical estuary Estuarine , Coastal and Shelf Science Response of soft-bottom macrobenthic assemblages to artisanal trawling fi sheries in a subtropical estuary. Estuarine, Coastal and Shelf Science 207: 142-153. DOI: 10.1016/j. ecss.2018.04.007

Ospina-Álvarez N., Piferrer F. 2008. Temperaturedependent sex determination in fish revisited: Prevalence, a single sex ratio response pattern, and possible effects of climate change. PLoS ONE 3 (7): e2837. DOI: 10.1371/journal.pone.0002837

Peixoto S.P., Calazans N., Silva E.F., Nole L., Soares R., Lucena Frédou F. 2018. Reproductive cycle and size at first sexual maturity of the white shrimp Penaeus schmitti (Burkenroad, 1936) in northeastern Brazil. Latin American Journal of Aquatic Research 46 (1): 1-9.

Pereira L.S., Agostinho A.A., Delariva R.L. 2016. Effects of river damming in Neotropical piscivorous and omnivorous fish: Feeding, body condition and abundances. Neotropical Ichthyology 14 (1): 267-278. DOI: 10.1590/1982-0224-20150044

Perelman J.N., Schmidt K.N., Haro I., Tibbetts I.R., Zischke M.T. 2017. Feeding dynamics, consumption rates and daily ration of wahoo Acanthocybium solandri in Indo-Pacific waters. Journal of Fish Biology 90 (5): 1842-1860. DOI: $10.1111 /$ jfb.13270

Pérez Roda M.A., Gilman E., Huntington T., Kennelly S.J., Suuronen P., Chaloupka M., Medley P. 2019. A third assessment of global marine fisheries discards. FAO Fisheries and Aquaculture Technical Paper 633. FAO, Rome.

Pinkas L., Oliphant M.S., Iverson I.L.K. 1971. Food habits of albacore, bluefin tuna, and bonito In California waters. Fish Bulletin 152: 1-105.

Plazas-Gómez R.A., Posada-Peláez C., Bustos-Montes D., Grijalba-Bendeck L.M. 2018. Bycatch of the Isla del Rosario (Gulf of Salamanca, Colombian Caribbean) artisanal shrimp fishery in an approximation to the biodiversity impact. Latin American Journal of Aquatic Research 46 (4): 690-698.

Pombo M., Denadai M.R., Bessa E., Santos F.B., de Faria V.H., Turra A. 2014. The barred grunt Conodon nobilis (Perciformes: Haemulidae) in shallow areas of a tropical bight: Spatial and temporal distribution, body growth and diet. Helgoland Marine Research 68 (2): 271-279. DOI: 10.1007/s10152-014-0387-2

R Development Core Team 2018. A language and environment for statistical computing $\mathrm{R}$ Foundation for Statistical Computing, Vienna, Austria.

Robinson O.J., Jensen O.P., Provost M.M., Huang S., Fefferman N.H., Kebir A., Lockwood J.L. 2017. 
Evaluating the impacts of fishing on sex-changing fish: A game-theoretic approach. ICES Journal of Marine Science 74 (3): 652-659. DOI: 10.1093/icesjms/fsw222

Rodrigues-Filho J.L., Branco J.O., Monteiro H.S., Verani J.R., Barreiros J.P. 2015. Seasonality of ichthyofauna bycatch in shrimp trawls from different depth strata in the southern Brazilian coast. Journal of Coastal Research 31 (2): 378-389. DOI: 10.2112/ JCOASTRES-D-13-00024.1

Rothlisberg P.C., Okey T.A. (eds.) 2007. Variation in banana prawn catches at Weipa: A comprehensive regional study. Fisheries. FRDC Project No. 2004/024. Final report, June 2007. CSIRO Marine and Atmospheric Research, Cleveland, Australia.

Santos M.C.F. 2010. Ordenamento da pesca de camarões no nordeste do Brasil. [Managment of the shrimp fishery in the Northeast of the Brazil.] Boletim Técnico-Científico do CEPENE 18 (1): 91-98. [In Portuguese.]

Shephard S., Brophy D., Reid D.G. 2010. Can bottom trawling indirectly diminish carrying capacity in a marine ecosystem?. Marine Biology 157 (11): 23752381. DOI: $10.1007 / \mathrm{s} 00227-010-1502-9$

Silva E.F., Calazans N., Nolé L., Branco T.C., Soares R., Guerra M.M.P., Lucena Frédou F., Peixoto S. 2016. Reproductive dynamics of the southern pink shrimp Farfantepenaeus subtilis in northeastern Brazil. Aquatic Biology 25: 29-35. DOI: 10.3354/ ab00653

Silva E.F., Calazans N., Nolé L., Soares R., Lucena Frédou F., Peixoto S. 2018. Population dynamics of the white shrimp Litopenaeus schmitti (Burkenroad, 1936) on the southern coast of Pernambuco, northeastern Brazil. Journal of the Marine Biological Association of the United Kingdom 99 (2): 429-435. DOI: $10.1017 / \mathrm{S} 0025315418000322$

Silva E.F., Viana A., Nolé L., Soares R., Peixoto S., Lucena-Frédou F., Calazans N. 2015. Population dynamics of the pink shrimp Farfantepenaeus subtilis (Pérez-Farfante, 1967) in northeastern Brazil. Journal of Crustacean Biology 35 (2): 132-139. DOI: 10.1163/1937240X-00002325

Silva-Júnior C.A.B, Lira A.S., Eduardo L.N., Viana A.P., Lucena-Frédou F., Frédou T. 2019. Ichthyofauna bycatch of the artisanal fishery of penaeid shrimps in Pernambuco, northeastern Brazil. Boletim do Instituto de Pesca 45 (1): e435. DOI: 10.20950/1678-2305.2019.45.1.435

Silva Júnior C.A.B., Viana A.P., Lucena Frédou F., Frédou T. 2015. Aspects of the reproductive biology and characterization of Sciaenidae captured as bycatch in the prawn trawling in the northeastern Brazil. Acta Scientiarum. Biological Sciences 37 (1): 1-8. DOI: 10.4025/actascibiolsci.v37i1.24962

Stratoudakis Y., Bernal M., Ganias K., Uriante A. 2006. The daily egg production method: Recent advances, current applications and future challenges.
Fish and Fisheries 7 (1): 35-57. DOI: 10.1111/j.14672979.2006.00206.x

Tirado-Ibarra J.J., Loya-Rodriguez M., MoralesArevalo J.C., Muñoz-Garcia I.R., Martinez-Perez F., Ramirez-Perez J.S., Jimenez-Gutierrez L.R. 2018. Reproduction and community structure of fish from winter catch sites from industrial shrimp bycatch from the northeast and southeast Mexican Pacific. PeerJ 6: e4460. DOI: $10.7717 /$ peerj.4460

Tischer M., Santos M.C.F. 2003. Composição e diversidade da ictiofauna acompanhante de peneídeos no litoral sul de Pernambuco. [Composition and diversity of the by-catch from penaeid fisheries off southern Pernambuco State, Brazil.] Arquivos de Ciência do Mar 36 (1-2): 105-118. [In Portuguese.]

Todorov V., Filzmoser P. 2009. An object-oriented framework for robust multivariate analysis. Journal of Statistical Software 32 (3): 1-47. DOI: 10.18637/jss. v032.i03

Tsagarakis K., Palialexis A., Vassilopoulou V. 2014. Mediterranean fishery discards: Review of the existing knowledge. ICES Journal of Marine Science 71 (5): 1219-1234. DOI: 10.1093/icesjms/fst074

Vasconcelos Filho A.L., Neumann-Leitão S., EskinaziLeça E., Oliveira A.M.E. 2010. Hábitos alimentares de peixes consumidores secundários do Canal de Santa Cruz, Pernambuco, Brasil. [Feeding habits of secondary consumer fishes of the Santa Cruz Channel, Pernambuco, Brazil.] Tropical Oceanography 38 (2): 121-128. [In Portuguese.] DOI: 10.5914/tropocean. v38i2.5166

Vazzoler A.E.A.M. 1996. Biologia da reprodução de peixes teleósteos: teoria e pratica. [Reproduction biology of teleost fish: Theory and practice.] EDUEM, Maringá, Brazil. [In Portuguese.]

Vieira W.J., Domingos M.M., Rodrigues-Filho J.L., de Farias E.G.G. 2017. Kite escape device: A new approach to reduce bycatch in shrimp trawls. Marine and Coastal Fisheries 9 (1): 396-403. DOI: 10.1080/19425120.2017.1347114

Wells R.J.D., Cowan J.H.jr., Patterson W.F.III 2008. Habitat use and the effect of shrimp trawling on fish and invertebrate communities over the northern Gulf of Mexico continental shelf. ICES Journal of Marine Science 65 (9): 1610-1619. DOI: 10.1093/icesjms/ fsn 145

Wolff M., Taylor M.H., Tesfaye G. 2015. Implications of using small meshed gillnets for the sustainability of fish populations: A theoretical exploration based on three case studies. Fisheries Management and Ecology 22 (5): 379-387. DOI: 10.1111/fme.12137

Zar J.H. 2009. Biostatistical analysis. 5th edn. Prentice Hall, Upper Saddle River, NJ, USA.

Received: 17 October 2018 Accepted: 8 August 2019 Published electronically: 15 December 2019 